\title{
PENYIMPANGAN PRINSIP KESANTUNAN BERBAHASA DALAM INTERAKSI BELAJAR-MENGAJAR BAHASA INDONESIA SISWA KELAS XI SMA NEGERI 2 PANCA RIJANG SIDENRENG RAPPANG
}

(The Deviations of Language Politeness Principle in Learning-Teaching Interaction in Bahasa Indonesia of Class XI Students at SMAN 2 Panca Rijang Sidenreng Rappang)

\author{
Musyawir \\ Universitas Iqra Buru \\ Jln. Prof. Dr. A. Basalamah, M.Si., Namlea, Maluku \\ Pos-el: musyawir.rs@gmail.com
}

(Diterima: 11 November 2018; Direvisi: 19 Februari 2019; Disetujui: 25 Mei 2019)

\begin{abstract}
The research aims to describe the types of deviation of language politeness principle and the cause of deviation. The research was qualitative. The data of the research were all of the students' speeches or oral conversation discourse and speech information situation. The data source was obtained from the students of class XI at SMAN 2 Panca Rijang Sidenreng Rappang.The data of the research were collected by recording, note-king, and unstructured interview technique. The data of the research were analyzed through four stages, namely data collections, data reduction, presentation, as well as data analysis and conclusions/verification. The results of the research reveal that the deviations of language politeness principle which were occurred in learning-teaching interaction in Bahasa Indonesia of class XI students at SMAN 2 Panca Rijang Sidenreng Rappang are single and double deviation. The causes of the deviation of language politeness principle in learning-teaching interactions in Bahasa Indonesia of class XI students at SMAN 2 Panca Rijang Sidenreng Rappang cover (1) deviation caused by the speakers intentionally accused the speaking partner, (2) intentionally speak not accordance with the context, (3) protective on opinion, (4) the speaker's emotional impulse, (5) direct critic with harsh words, (6) mocking, and (7) no sympathy given to the speaking partner.
\end{abstract}

Keywords: learning-teaching interaction, language politeness, politeness principle.

Abstrak

Penelitian ini bertujuan untuk mendeskripsikan jenis-jenis penyimpangan prinsip kesantunan berbahasa dan penyebab penyimpangan. Jenis penelitian ini tergolong penelitian kualitatif. Data dalam penelitian ini adalah seluruh tuturan siswa atau wacana percakapan lisan dan informasi situasi tutur. Adapun sumber data diperoleh dari siswa kelas XI SMA Negeri 2 Panca Rijang Sidenreng Rappang. Teknik pengumpulan data yang digunakan adalah teknik rekam, teknik catat, dan wawancara tidak terstruktur. Analisis data melalui empat tahapan,yakni pengumpulan data, reduksi data, penyajian sekaligus penganalisisan data dan penyimpulan /verifikasi. Hasil penelitian menunjukkan bahwa penyimpangan prinsip kesantunan berbahasa yang terjadi dalam interaksi belajar-mengajar bahasa Indonesia siswa kelas XI SMA Negeri 2 Panca Rijang Sidenreng Rappang, yakni penyimpangan tunggal dan penyimpangan ganda. Penyebab penyimpangan prinsip kesantunan berbahasa dalam interaksi belajar-mengajar bahasa Indonesia siswa kelas XI SMA Negeri 2 Panca Rijang Sidenreng Rappang meliputi (1) penyimpangan disebabkan oleh penutur sengaja menuduh mitra tutur, (2) sengaja berbicara tidak sesuai dengan konteks, (3) protektif terhadap pendapat, (4) dorongan rasa emosi penutur, (5) kritik secara langsung dengan kata-kata kasar, dan (6) mengejek, serta (7) tidak memberikan rasa simpati kepada mitra tutur.

Kata-kata kunci: interaksi belajar-mengajar, kesantunan berbahasa, prinsip kesantunan.

\section{PENDAHULUAN}

Manusia sebagai makhluk sosial pasti selalu berkomunikasi atau berinteraksi untuk menyampaikan pesan dan menjalin hubungan antarsesama. Komunikasi merupakan hal yang penting demi terbentuknya suatu kelompok masyarakat, sehingga untuk dapat berinteraksi antarsesama kelompok masyarakat, baik masyarakat umum maupun masyarakat khusus seperti di sekolah, maka diperlukan suatu alat yang disebut bahasa. Bahasa merupakan media komunikasi yang utama dalam suatu masyarakat. Dengan bahasa seseorang dapat mengungkapkan gagasan, perasaan, dan kemampuan seseorang kepada orang lain dalam suatu kelompok sosial tertentu. Selain itu, bahasa juga selalu digunakan manusia dalam memahami berbagai konsep demi memenuhi kebutuhan hidupnya. Sehubungan dengan hal tersebut, sangat diharapkan terwujud manusia yang cerdas dan bijaksana dalam berperilaku. Bahasa merupakan sarana yang digunakan oleh manusia untuk berkomunikasi atau berinteraksi. Oleh karena itu, setiap orang dituntut mampu berbahasa (Musaba, 2012:2). Selain itu, interaksi yang dilakukan oleh manusia bukan hanya bertujuan untuk menyampaikan pesan, tetapi juga menjalin hubungan sosial. Relevansi dengan hubungan sosial dan komunikasi antarsesama manusia dibatasi oleh nilai-nilai dalam masyarakat. 
Bahasa yang santun merupakan sarana yang paling tepat digunakan untuk berkomunikasi dan menjalin hubungan sosial. Hal tersebut disebabkan oleh bahasa yang santun memperhatikan kaidah kebahasaan dan tatanan nilai yang berlaku di dalam masyarakat. Memang tidak dapat disangkal, realitas kehidupan masyarakat secara umum saat ini, semakin hari semakin merujuk pada penggunaan bahasa yang tidak memperhatikan prinsip kesantunan berbahasa dalam berkomunikasi. Hal tersebut terlihat pada kondisi masyarakat yang penuh dengan perkelahian antarsesama akibat dari bahasa yang digunakan tidak sesuai dengan tatanan nilai dan etika yang ada dalam masyarakat tersebut. Berbahasa santun seharusnya mendapat perhatian khusus bagi pengguna bahasa dalam kehidupan bermasyarakat. Jika bahasa santun digunakan dalam berinteraksi secara konsisten, maka akan tercipta suatu kondisi masyarakat yang damai, tenang, dan harmonis. Untuk mewujudkan kondisi masyarakat tersebut, faktor yang sangat menentukan dalam proses pelestarian dan pewarisan budaya berbahasa santun di masa depan terletak pada generasi muda saat ini.

Berbahasa santun seharusnya sudah menjadi suatu tradisi yang dimiliki oleh setiap individu sejak kecil. Setiap anak perlu dibina dan dididik dalam menggunakan bahasa yang santun ketika sedang berkomunikasi dengan sesamanya, sebab merekalah sebagai generasi penerus yang mengarahkan bangsa ini di masa yang akan datang. Selain itu, kesantunan berbahasa di lingkungan sekolah dalam interaksi belajar-mengajar memiliki nilai yang sangat urgen.

Bahasa yang santun merupakan sarana yang paling tepat digunakan dalam berkomunikasi. Siswa perlu dibina dan diarahkan berbahasa santun, sebab siswa merupakan generasi penerus yang akan hidup sesuai dengan zamannya. Siswa yang dibiarkan berbahasa tidak santun, mengakibatkan generasi selanjutnya adalah generasi yang arogan, kasar, jauh dari nilainilai etika, agama, dan tidak berkarakter. Ungkapan dari bahasa yang kasar dan arogan inilah yang seringkali menyebabkan perselisihan dan perkelahian di kalangan antarpelajar.

Perkelahian bahkan tawuran antarpelajar, sering terjadi akibat penggunaan bahasa dengan tidak memperhatikan prinsip kesantunan berbahasa. Jika para pelajar ini terus-menerus tidak menggunakan bahasa yang santun, maka terciptalah kondisi masyarakat yang tidak damai, tidak tenang, dan tidak harmonis.

Seiring dengan perkembangan zaman, 18 sa Indonesia mempunyai peranan yang sangat urgen dan strategis dalam proses komunikasi. Seseorang akan mampu berkomunikasi secara lisan maupun tulis sesuai dengan konteks dan situasinya, jika ia menguasai bahasa yang baik dan benar. Tuturan dalam bahasa Indonesia secara umum sudah dianggap santun jika penutur menggunakan kata-kata yang santun, tuturannya tidak memerintah secara langsung, dan menghormati orang lain. Kesantunan berbahasa, khususnya dalam komunikasi verbal dapat dilihat dari beberapa indikator di antaranya adanya maksim-maksim kesantunan yang terdapat dalam tuturan.

Kesantunan berbahasa dapat dijadikan barometer dari kesantunan sikap, kepribadian, dan budi pekerti yang dimiliki seseorang. Sekolah sebagai institusi pendidikan formal memiliki fungsi dan peran strategis untuk menghasilkan generasi-generasi masa depan yang terampil berbahasa Indonesia yang baik, benar, dan sopan. Melalui pengajaran bahasa Indonesia, para peserta didik diajak untuk berlatih dan belajar berbahasa melalui aspek keterampilan mendengarkan, berbicara, membaca, dan menulis.

Jenjang pendidikan tingkat Sekolah Dasar (SD), Sekolah Menegah Pertama (SMP), dan Sekolah Menengah Atas (SMA) sejak tahun pengajaran 2014-2015 hingga sekarang diharuskan sudah menggunakan Kurikulum 2013. Kompetensi inti pengajaran bahasa Indonesia dalam Kurikulum 2013 lebih terpusat pada aspek keterampilan menulis dan membaca. Sehingga keterampilan berbicara dalam Kurikulum 2013 kurang mendapat perhatian khusus. Oleh karena itu, guru bahasa Indonesia harus mampu mengajarkan aspek keterampilan berbicara melalui interaksi belajar-mengajar, karena keterampilan berbicara sangat dibutuhkan dalam kegiatan interaksi sosial.

Beberapa penelitian yang relevan mengenai penyimpangan prinsip kesantunan berbahasa di antaranya adalah Anand Firmansyah (2011) melakukan penelitian dengan judul Penyimpangan Prinsip Kerja Sama dan Prinsip Kesantunan dalam Wacana Humor Verbal Tulis pada Buku Mang Kunteng. Penulis melakukan penelitian dalam bidang pragmatik berupa tuturan verbal tulis yang terdapat pada buku Mang Kunteng. Subjek penelitian ini adalah buku Mang Kunteng, objek penelitiannya adalah penyimpangan prinsip kerja sama dan prinsip kesantunan. Hasil penelitian tersebut berupa deskripsi penyimpangan prinsip kerja sama dan prinsip kesantunan dalam setiap kelompok humor pada buku Mang Kunteng.

Selain itu, Aldila Fajri Nur Rohma (2010) melakukan penelitian dengan judul "Analisis Penggunaan dan Penyimpangan 
Prinsip Kesantunan Berbahasa di Terminal Giwangan Yogyakarta". Peneliti melakukan penelitian dalam bidang pragmatik berupa tuturan lisan yang terjadi di terminal Giwangan Yogyakarta. Subjek penelitian ini adalah semua peristiwa berbahasa yang terjadi di terminal Giwangan. Hasil penelitian tersebut berisi deskripsi jenis penyimpangan dan penggunaan prinsip kesantunan dan faktor yang melatarbelakangi penyimpangan dan penggunaan prinsip kesantunan berbahasa di terminal Giwangan.

Persamaan dari kedua penelitian tersebut dibandingkan dengan penelitian ini adalah sama-sama meneliti tentang prinsip kesantunan beserta maksim-maksimnya, sedangkan perbedaannya adalah unsur yang dikaji dan subjek kajian. Penelitian Aldila mengkaji penggunaan dan penyimpangan prinsip kesantunan berbahasa di terminal Giwangan yang subjeknya adalah semua peristiwa berbahasa yang terjadi di terminal Giwangan, sedangkan pada penelitian ini mengkaji unsur pendidikan yang subjek kajiannya adalah tuturan siswa dan guru dalam pengajaran bahasa Indonesia.

Perbedaan penelitian ini dengan penelitan Anand yakni pada penelitian Adnan subjeknya berupa buku Mang Kunteng, yang merupakan bahasa verbal tulis, sedangkan pada penelitian ini subjeknya adalah tuturan siswa dan guru dalam pengajaran bahasa Indonesia yang berupa bahasa lisan.

Berdasarkan latar belakang masalah tersebut, maka penulis merumuskan beberapa masalah penelitian. Adapun masalah penelitian yang dimaksud adalah bagaimanakah jenis penyimpangan prinsip kesantunan berbahasa yang terjadi dalam interaksi belajar-mengajar bahasa Indonesia siswa kelas XI SMA Negeri 2 Panca Rijang Sidenreng Rappang? Dan mengapa penyimpangan prinsip kesantunan berbahasa dapat terjadi dalam interaksi belajar-mengajar bahasa Indonesia siswa kelas XI SMA Negeri 2 Panca Rijang Sidenreng Rappang?

Tujuan penelitian ini adalah untuk mendeskripsikan jenis penyimpangan prinsip kesantunan berbahasa yang terjadi dalam interaksi belajar-mengajar bahasa Indonesia siswa kelas XI SMA Negeri 2 Panca Rijang Sidenreng Rappang dan mendeskripsikan penyebab penyimpangan prinsip kesantunan berbahasa dalam interaksi belajar-mengajar bahasa Indonesia siswa kelas XI SMA Negeri 2 Panca Rijang Sidenreng Rappang.

\section{LANDASAN TEORI}

Pragmatik adalah ilmu yang mengkaji makna tuturan, sedangkan semantik adalah ilmu yang mengkaji makna kalimat; pragmatik mengkaji makna dalam hubungannya dengan situasi ujaran (Leech, 1993:21). Pragmatik adalah studi tentang maksud penutur, studi tentang makna kontekstual, studi tentang tuturan agar lebih banyak tersampaikan daripada yang dituturkan, dan studi tentang ungkapan dari jarak hubungan (Yule, 1996:34). Soeparno (2002:27), "pragmatik adalah subdisiplin linguistik yang mempelajari penerapan atau penggunaan bahasa dalam komunikasi sosial yang harus selalu memperhatikan faktor-faktor situasi, maksud pembicaraan, dan status lawan tutur". Dengan demikian, Hal itu dapat disimpulkan bahwa pragmatilk merupakan cabang ilmu bahasa yang mempelajari penggunaan bahasa dalam komunikasi sosial yang memperhatikan konteks. Selain itu, Wijana dan Rohmadi, (2009:3-4) juga mengemukakan bahwa pragmatik merupakan cabang ilmu bahasa yang mempelajari struktur bahasa secara eksternal, yaitu bagaimana satuan kebahasaan itu digunakan di dalam berkomunikasi.

Kesantunan merupakan aturan perilaku yang ditetapkan dan disepakati bersama oleh suatu masyarakat tertentu sehingga kesantunan sekaligus menjadi prasyarat yang disepakati oleh perilaku sosial. Selain itu, Menurut Bruce Fraser dan William Nolem (dalam Eelen 2006:15) kesantunan disebut sebagai sikap untuk tetap berada dalam syarat-syarat dan kondisi yang berlaku dalam kontak percakapan, sedangkan ketidaksantunan merupakan pelanggaran terhadap syarat-syarat dan kondisi yang berlaku dalam kontak percakapan. Selain itu, menurut Zamzani, dkk. (2010:2), "kesantunan (politeness) merupakan perilaku yang diekspresikan dengan cara yang baik atau beretika". Sebagai kesimpulan, kesantunan merupakan fenomena kultural, sehingga apa yang dianggap santun oleh suatu kultur mungkin tidak demikian halnya dengan kultur yang lain. Tujuan kesantunan, termasuk kesantunan berbahasa, adalah membuat suasana berinteraksi dengan menyenangkan, tidak mengancam muka dan efektif. Pakar lain yang mengemukakan tentang teori kesantunan adalah Leech. Dia menempatkan kesantunan dalam kerangka retorika interpersonal. Asumsi yang disampaikan berawal dari perbedaan antara semantik dan pragmatik. Semantik berkaitan dengan makna kalimat, sedangkan pragmatik terkait dengan hubungan rasa sebuah kalimat. Teori kesantunan didasarkan pada prinsip kerja sama. Hubungan antara prinsip kerja sama dan prinsip kesantunan dijelaskan oleh Leech bahwa apabila prinsip kooperatif dilanggar, prinsip tersebut dapat mengacu pada prinsip kesantunan. Teori kesantunan Leech dijabarkan dalam bentuk maksim atau ketentuan. Maksim yang 
dikemukakan ada enam, yaitu (1) maksim kebijaksanaan, (2) maksim penerimaan, (3) maksim kemurahan, (4) maksim kerendahan hati, (5) maksim kesetujuan, (6) maksim kesimpatian. Tiap-tiap maksim tersebut dijabarkan secara rinci berikut ini.

(1)Maksim kebijaksanaan menghendaki penutur dan lawan tutur harus meminimalkan kerugian dan memaksimalkan keuntungan bagi orang lain.

(2)Maksim penerimaan menghendaki penutur dan lawan tutur memaksimalkan kerugian bagi dirinya sendiri dan meminimalkan keuntungan diri sendiri.

(3)Maksim kemurahan menghendaki penutur dan lawan tutur memaksimalkan rasa hormat kepada orang lain dan meminimalkan rasa tidak hormat kepada orang lain.

(4)Maksim kerendahan hati menghendaki memaksimalkan ketidakhormatan kepada lawan tutur dan meminimalkan rasa hormat kepada diri sendiri.

(5)Maksim kecocokan menghendaki penutur dan lawan tutur memaksimalkan kesetujuan di antara mereka dan meminimalkan ketidaksetujuan di antara mereka.

(6)Maksim kesimpatian menghendaki penutur dan lawan tutur memaksimalkan rasa simpati dan meminimalkan rasa antipati kepada lawan tuturnya.

Berdasarkan maksim-maksim tersebut, Leech (dalam Chaer, 2010) mengemukakan lima skala sebagai pengukur kesantunan berbahasa. Skala tersebut, yaitu (a) skala kerugian dan keuntungan dalam pertuturan, artinya semakin merugikan penutur, maka semakin santunlah tuturan tersebut, (b) skala pilihan berdasar pada banyak sedikitnya pilihan dalam bertutur, artinya semakin banyak keleluasaan pilihan dalam bertutur, maka semakin santunlah tuturan itu, (c) skala ketidaklangsungan merujuk pada langsung atau tidak langsung suatu tuturan, artinya semakin tidak langsung maksud tuturan, maka semakin santunlah tuturan tersebut, (d) skala keotoritasan merujuk pada hubungan status sosial dalam tuturan, artinya semakin jauh jarak sosial seseorang, cenderung akan semakin santunlah tuturan tersebut, dan (e) skala jarak sosial merujuk kepada hubungan sosial dalam tuturan, artinya semakin jauh jarak hubungan sosial seseorang, maka semakin santunlah dia dalam mengemukakan tuturan.

Proses belajar-mengajar merupakan inti dari kegiatan pendidikan di sekolah. Kegiatan belajar adalah kegiatan yang primer $20 \mathrm{~m}$ proses belajar-mengajar, sedangkan 20 atan mengajar merupakan kegiatan sekunder yang dimaksudkan untuk mewujudkan kegiatan belajar yang optimal. Kegiatan belajar-mengajar merupakan satu kesatuan dari dua kegiatan yang searah (Dimyati, 1992:10). Menurut Atar Semi (1995:49), mengajar memang bukan merupakan istilah baru, namun maknanya belum tentu pula sama bagi setiap orang. Di dalam pembahasan ini, mengajar diartikan sebagai penciptaan suatu sistem lingkungan yang memungkinkan terjadinya proses belajar. Sistem lingkungan ini terdiri atas komponenkomponen yang saling memengaruhi: tujuan instruksional, materi yang diajarkan, guru dan siswa yang memainkan peranan, bentuk kegiatan yang dilakukan, serta media atau sarana yang tersedia. Komponen-komponen tersebut saling berpengaruh secara bervariasi, sehingga setiap peristiwa belajar-mengajar memiliki "wajah" sendiri yang unik. Untuk mencapai tujuan instruksional tertentu dinamakan efek instruksional (instructional effects) yang biasanya berbentuk pengetahuan dan keterampilan.

\section{METODE}

Penelitian ini berjudul Penyimpangan Prinsip Kesantunan Berbahasa dalam Interaksi Belajar-Mengajar Bahasa Indonesia Siswa Kelas XI SMA Negeri 2 Panca Rijang Sidenreng Rappang. Penelitian ini merupakan penelitian kualitatif. Karakteristik kualitatif yang dimiliki penelitian ini, yakni (a) data bersumber dari tuturan siswa dan guru pada saat interaksi belajar-mengajar bahasa Indonesia di kelas secara alami, (b) hasil penelitian memberikan deskripsi data penyimpangan prinsip kesantunan berbahasa siswa berdasarkan gejala atau fenomena yang diteliti secara induktif, (c) peneliti sebagai instrumen utama pengumpulan data dan analisis data, dan (d) data yang dikumpulkan berbentuk kata-kata atau tuturan (Moleong, 1990).

Penelitian ini difokuskan pada pada tuturan yang terjadi dalam interaksi belajarmengajar bahasa Indonesia untuk mengetahui wujud jenis dan penyebab penyimpangan prinsip kesantunan berbahasa dalam interaksi belajar-mengajar bahasa Indonesia siswa kelas XI SMA Negeri 2 Panca Rijang Sidenreng Rappang.

Data dalam penelitian ini adalah seluruh tuturan atau wacana percakapan lisan dan informasi situasi percakapan. Sumber data dalam penelitian ini adalah siswa kelas XI SMA Negeri 2 Panca Rijang Sidenreng Rappang. Selanjutnya, jumlah kelas yang akan menjadi sampel penelitian di sekolah tersebut sebanyak enam kelas dengan rincian, yaitu empat kelas untuk kelas XI jurusan Ilmu Pengetahuan Alam (IPA) dan dua kelas untuk 
kelas XI jurusan Ilmu Pengetahuan Sosial (IPS).

Teknik dalam penelitian ini yaitu teknik rekam. Selain itu, teknik lain yang digunakan untuk mengumpulkan data dalam penelitian ini yaitu teknik catat dan metode wawancara tidak terstruktur. Peneliti pada metode simak dalam hal ini teknik rekam hanya sebagai pengamat penggunaan bahasa oleh para informan.

Keabsahan data dalam penelitian ini perlu dilakukan pengecekan untuk menjamin keabsahan data penelitian. Pengecekan keabsahan data dilakukan melalui objektivitas (comfirmability) dan kesahihan internal (creadibility). Untuk mencapai kondisi objektif, peneliti (1) mengkaji literatur yang relevan, (2) menetapkan fokus penelitian yang tepat, (3) instrumen dan cara pengumpulan data yang akurat, dan (4) analisis data secara benar (Iskandar, 2008:228-229). Selanjutnya, pengecekan keabsahan data dengan triangulasi. Menurut Sudaryanto (2003:30) triangulasi adalah teknik penentuan keabsahan data dengan cara pengecekan melalui cara yang berbeda dengan cara yang sudah dilakukan. Sehubungan dengan hal tersebut, triangulasi yang dilakukan dalam penelitian ini melalui tiga teknik, yaitu teknik teori, teknik sumber, dan teknik metode.

Analisis data dalam penelitian ini bermula dari pengumpulan data melalui transkripsi rekaman, catatan lapangan, dan hasil wawancara, kemudian dilakukan identifikasi, deskripsi, dan klasifikasi data berdasarkan penyimpangan maksim kesantunan. Selanjutnya, peneliti melakukan tahap reduksi data, memilih data yang relevan dengan fokus penelitian. Kemudian dilakukan tahap penyajian sekaligus penganalisisan data dengan teori pragmatik. Geoffrey Leech tentang prinsip-prinsip kesantunan berbahasa dan kegiatan penganalisisan data dapat pula dilakukan dengan menggunakan kartu data. Selanjutnya, data yang sudah dianalisis selanjutnya terekap dalam lembar rekaman data sehingga diketahui kuantitas penyimpangan prinsip kesantunan berbahasa. Hasil analisis tersebut disimpulkan dan diklasifikasi berdasarkan fokus penelitian, yaitu jenis penyimpangan prinsip kesantunan berbahasa yang terjadi dan penyebab sehingga terjadi penyimpangan prinsip kesantunan berbahasa.

\section{PEMBAHASAN}

Hasil penelitian berupa deskripsi jenisjenis penyimpangan prinsip kesantunan berbahasa dalam interaksi belajar-mengajar bahasa Indonesia siswa kelas XI SMA Negeri 2 Panca Rijang Sidenreng Rappang dan penyebab penyimpangan prinsip kesantunan berbahasa tersebut. Berdasarkan data yang diperoleh dalam penelitian, ditemukan adanya penyimpangan prinsip kesantunan berbahasa dalam interaksi belajar-mengajar bahasa Indonesia siswa kelas XI SMA Negeri 2 Panca Rijang Sidenreng Rappang. Penyimpangan tersebut, baik yang disengaja maupun tidak disengaja, dilakukan oleh partisipan dengan alasan-alasan tertentu. Keseluruhan data yang terkumpul berdasarkan jumlah kartu data yaitu 131 data percakapan yang menyimpang dari prinsip kesantunan berbahasa selama dua puluh empat kali pertemuan efektif. Dari sekian banyak kartu data tersebut, terbagi atas penyimpangan maksim-maksim dalam prinsip kesantunan berbahasa.

Jenis-jenis prinsip kesantunan berbahasa yang menyimpang meliputi penyimpangan tunggal dan penyimpangan ganda. Penyimpangan tunggal meliputi penyimpangan maksim kearifan, penyimpangan maksim kedermawanan, penyimpangan maksim pujian, penyimpangan maksim kerendahan hati, penyimpangan maksim kesepakatan, dan penyimpangan maksim kesimpatian. Beberapa wujud hasil penelitian, yaitu:

(1)Penyimpangan prinsip kesantunan berbahasa dalam interaksi belajarmengajar bahasa Indonesia

a) Penyimpangan satu maksim atau penyimpangan tunggal

1. Maksim kearifan

Maksim kearifan mengatur sebuah tuturan agar tidak memberatkan lawan tutur dan terasa lebih halus. Seseorang dalam menghasilkan sebuah tuturan harus bersikap arif. Penyimpangan maksim kearifan terjadi sebanyak 39 kali pada data yang telah dianalisis. Penyimpangan terhadap maksim kearifan dapat ditandai dengan penutur menggunakan diksi yang tidak halus, memerintah secara langsung, menegur secara langsung, memberi saran secara langsung, menolak dengan nada tinggi, dan menolak dengan kasar. Penyimpangan maksim kearifan dapat dilihat pada beberapa data berikut.

Guru : "Baik, pertemuan yang lalu Ibu telah menyuruh kalian membawa contoh tajuk rencana, sudah bawa semua?"

Siswa 1 : "Sudah, Bu".

Siswa 2 : "Sudah ada juga punyaku, Bu".

Guru : : "Ada yang tidak bawa tajuk rencana?"

Siswa 3 : "Fikram, Bu".

Guru : : "Mengapa tidak bawa tugas tajuk rencana, Nak?"

Siswa 4 : "Tidak ada saya dapat, Bu". (Data 01.01). 
Tuturan tersebut disampaikan oleh guru kepada siswa dengan maksud ingin menanyakan (menagih) tugas yang diberikan, dan siswa tersebut merespons pertanyaan guru atau menolak dengan nada yang tinggi sedikit emosi tanpa memberi alasan yang jelas. Penyimpangan maksim kearifan pada data tersebut karena siswa tidak bersikap arif menyampaikan sebuah tuturan. Tuturan pada data tersebut menjadi tidak santun karena tuturan siswa (4) tersebut yakni "tidak ada saya dapat, Bu", terkesan siswa emosi dan menolak dengan nada yang tinggi tanpa memberi alasan yang jelas. Tuturan menolak dengan nada yang tinggi termasuk ke dalam tuturan yang tidak arif, sehingga tuturan siswa tersebut menyimpang dari prinsip kesantunan maksim kearifan.

\section{Maksim kedermawanan}

Maksim kedermawanan menuntut setiap peserta pertuturan untuk memaksimalkan rasa hormat kepada orang lain, dan meminimalkan rasa tidak hormat kepada orang lain. Penyimpangan maksim kedermawanan terjadi 14 kali pada data yang telah dianalisis. Penyimpangan terhadap maksim kedermawanan dapat ditandai dengan tidak menghormati lawan tutur, tidak memberikan kesempatan pada mitra tutur untuk berpendapat, berprasangka buruk kepada mitra tutur, dan mempermalukan mitra tutur. Penyimpangan maksim kedermawanan dapat dilihat pada beberapa data berikut.

Siswa1 : "Bu, engkare tori matingro bawang natungkae". (Bu, ada itu selalu tidur, kerjanya selalu tidur).

Siswa 2 : "Tidak tidur itu Bu, dia kurang sehat, Bu".

Guru : "Kamu sakit apa, Nak?"

Siswa 3 : “Sakit kepalanya, Bu”. (Data 01.07).

Tuturan tersebut disampaikan oleh siswa kepada siswa pada saat siswa sedang mengerjakan tugas dan seorang siswa menunduk di meja, belakang pojok kelas. Penyimpangan maksim kedermawanan pada data tersebut karena siswa tidak menunjukkan kedermawanan menyampaikan sebuah tuturan. Tuturan pada data tersebut menjadi tidak santun karena tuturan siswa (1) tersebut yakni " $\mathrm{Bu}$, engkare tori matingro bawang natungkae". (Bu, ada itu selalu tidur, kerjanya selalu tidur), terkesan siswa berprasangka buruk kepada teman dan mempermalukan teman. Tuturan berprasangka buruk kepada teman dan mempermalukan teman termasuk ke dalam tuturan yang tidak menunjukkan kedermawanan, sehingga tuturan siswa tersebut menyimpang dari prinsip kesantunan maksim kedermawanan.

22 - Taksim pujian
Maksim pujian menuntut setiap peserta tindak tutur memaksimalkan kerugian bagi diri sendiri, dan meminimalkan keuntungan diri sendiri. Penyimpangan maksim pujian terjadi empat kali pada data yang telah dianalisis. Penyimpangan terhadap maksim pujian dapat ditandai dengan memberikan kritik yang menjatuhkan orang lain, berbicara yang menyakiti hati orang lain, tidak mengucapkan "terima kasih" ketika mendapat saran/kritik dari orang lain, tidak menghargai orang lain, dan mementingkan kepentingan pribadi. Penyimpangan maksim pujian dapat dilihat pada beberapa data berikut.

Guru : "Baiklah, Ibu akan perjelas bahwa ringkasan itu berupa penyajian pokok-pokok penting tentang sesuatu tanpa mengubah makna aslinya dan cara merangkum itu harus ditemukan dulu ide pokok setiap paragraph. Setelah itu, ide pokok yang ditemukan itu disatukan menjadi suatu paragraf yang akhirnya disebut rangkuman". Sudah dipahami sampai di sini?"

Siswa 1 : "Iya, Bu sudah dipahami".

Siswa 2 : "Iya, Bu, lumayan, sudah dipahami sedikit". (Data 04.50).

Tuturan tersebut disampaikan oleh siswa kepada guru pada saat guru selesai menjelaskan materi dan langsung bertanya kepada siswa. Penyimpangan maksim pujian pada data tersebut karena siswa tidak menunjukkan pujian menyampaikan sebuah tuturan. Tuturan pada data tersebut menjadi tidak santun karena tuturan siswa (2) tersebut yakni "Iya, Bu lumayan, sudah dipahami sedikit", terkesan siswa tidak menghargai pendapat mitra tutur (guru). Tuturan tidak menghargai pendapat mitra tutur (guru) termasuk ke dalam tuturan yang tidak menunjukkan pujian, sehingga tuturan siswa tersebut menyimpang dari prinsip kesantunan maksim pujian.

\section{(4) Maksim kerendahan hati}

Maksim kerendahan hati menuntut setiap peserta pertuturan untuk memaksimalkan ketidakhormatan pada diri sendiri dan meminimalkan rasa hormat pada diri sendiri. Peserta tutur juga diharapkan dapat bersikap rendah hati dengan cara mengurangi pujian terhadap diri sendiri. Penyimpangan maksim kerendahan hati terjadi empat kali pada data yang telah dianalisis. Penyimpangan terhadap maksim kerendahan hati dapat ditandai dengan memaksakan kehendak, menonjolkan/memamerkan kelebihan diri sendiri pada orang lain, tidak tulus mencari-cari alasan, arogan, dan 
superior. Penyimpangan maksim kerendahan hati dapat dilihat pada data berikut.

Guru : "Sudah, silakan tenang!"mengapa ribut sekali di sana, apa lagi dibahas?"

Siswa1 : "Tenang Saudara, jangan ribut!"

Siswa 2: "Tidak ada, Bu".

Siswa 3: "Apa, Bu?, anu $\mathrm{Bu}$, tentang anu $\mathrm{Bu}$, e...tentang materi mojee

(hanya materi) Bu e". (Data 03.37).

Tuturan tersebut disampaikan oleh guru kepada siswa pada saat suasana belajar, siswa sangat ribut sehingga guru menertibkan dengan bertanya. Penyimpangan maksim kerendahan hati pada data tersebut karena siswa tidak menunjukkan kerendahan hati menyampaikan sebuah tuturan. Tuturan pada data tersebut menjadi tidak santun karena tuturan siswa (3) tersebut yakni "apa, Bu?, anu $\mathrm{Bu}$, tentang anu $\mathrm{Bu}$, e...tentang materi mojee (hanya materi) Bu e", terkesan siswa mencaricari alasan. Tuturan yang mencari-cari alasan termasuk ke dalam tuturan yang tidak menunjukkan kerendahan hati, sehingga tuturan siswa tersebut menyimpang dari prinsip kesantunan maksim kerendahan hati.

\section{Maksim kesepakatan}

Maksim kesepakatan menuntun setiap penutur dan mitra tutur untuk memaksimalkan kesepakatan di antara mereka, dan meminimalkan ketidaksepakatan di antara mereka. Penyimpangan maksim kesepakatan terjadi tiga kali pada data yang telah dianalisis. Penyimpangan terhadap maksim kesepakatan dapat ditandai dengan tidak memberikan pilihan kepada mitra tutur, berbicara tidak sesuai situasi/pokok permasalahan yang sedang dibicarakan, dan tidak ada kesepakatan antara penutur dan lawan tutur. Penyimpangan maksim kesepakatan dapat dilihat pada beberapa data berikut.

Guru : "Bawa ke sini dulu!, bapak akan lihat dulu, kemudian yang lain silakan dikumpul tugasnya kalau sudah selesai!, waktu sudah mau habis".

Siswa 1 : "Sudah selesai Pak".

Siswa 2 : "Alhamdulillah, selesai juga punyaku, Pak".

Siswa 3 : "Iya, Pak, cedde meni (sedikit lagi), Pak!". (Data 02.32).

Tuturan tersebut disampaikan oleh siswa kepada guru pada saat guru mengingatkan kepada siswa bahwa batas waktu mengerjakan tugas sudah habis dan tugas segera dikumpul. Penyimpangan maksim kesepakatan pada data tersebut karena siswa tidak menunjukkan kesepakatan menyampaikan sebuah tuturan. Tuturan pada data tersebut menjadi tidak santun karena tuturan siswa (3) tersebut yakni "iya, Pak, cedde meni (sedikit lagi), Pak!", terkesan siswa menolak atau tidak sepakat dengan mitra tutur (guru). Tuturan yang menunjukkan tidak ada kesepakatan antara penutur dan mitra tutur termasuk ke dalam tuturan yang tidak menunjukkan kesepakatan, sehingga tuturan siswa tersebut menyimpang dari prinsip kesantunan maksim kesepakatan.

\section{Maksim kesimpatian}

Maksim kesimpatian mengharuskan setiap peserta pertuturan untuk memaksimalkan rasa simpati dan meminimalkan rasa antipati kepada mitra tutur. Penutur harus menunjukkan bahwa ia merasa senang apabila mitra tutur merasakan kebahagiaan. Penutur juga harus menunjukkan simpati atas kesedihan mitra tutur apabila mitra tutur sedang merasakan kesedihan. Penyimpangan maksim kesimpatian terjadi dua kali pada data yang telah dianalisis. Penyimpangan terhadap maksim simpati dapat ditandai dengan tidak memberikan rasa simpati yang tulus kepada lawan tutur dan bersikap antipasti terhadap lawan tutur. Penyimpangan maksim kesimpatian dapat dilihat pada beberapa data berikut.

Siswa 1 :"Mana tugasmu, sudah selesai?"

Siswa 2 : "Sudah selesai Saudara, tapi siapa lagi yang ambil bukuku?".

Siswa 3 : "Saya kira ada di mejamu tadi".

Siswa 4: "Kenro memeng mutaro, ikotu punna bok, sappai!” (Di mana memang kamu simpan, kamu kan yang punya buku, cari!)”. (Data 06.103).

Tuturan tersebut disampaikan oleh siswa kepada siswa pada saat siswa sedang mengerjakan tugas, terdapat seorang siswa bertanya kepada temannya dan ingin langsung melihat pekerjaannya, namun buku teman tersebut tidak ada di mejanya. Penyimpangan maksim kesimpatian pada data tersebut karena siswa (4) tidak menunjukkan kesimpatian menyampaikan sebuah tuturan. Tuturan pada data tersebut menjadi tidak santun karena tuturan siswa (4) tersebut yakni "kenro memeng mutaro, ikotu punna bok, sappai!" (Di mana memang kamu simpan, kamu kan yang punya buku, cari!), terkesan siswa bersikap antipati terhadap mitra tutur (tidak menunjukkan rasa simpati atas kesedihan mitra tutur). Tuturan yang berikap antipati terhadap mitra tutur (tidak menunjukkan rasa simpati atas kesedihan mitra tutur) termasuk ke dalam tuturan yang tidak menunjukkan kesimpatian, sehingga tuturan siswa tersebut menyimpang dari prinsip kesantunan maksim kesimpatian.

\section{(b) Penyimpangan dua maksim atau penyimpangan ganda}

1. Maksim kearifan dan maksim kedermawanan 
Penyimpangan dua maksim dalam satu percakapan disebut penyimpangan ganda, termasuk penyimpangan maksim kearifan dan maksim kedermawanan. Dalam penyimpangan ini, peserta tutur melanggar maksim kearifan sekaligus maksim kedermawanan. Penyimpangan maksim kearifan dan maksim kedermawanan terjadi 34 kali pada data yang telah dianalisis. Penyimpangan maksim kearifan dan maksim kedermawanan dapat dilihat pada data berikut.

Guru : "Ada yang tidak bawa tajuk rencana?"

Siswa 1 : "Fikram, Bu".

Guru : "Mengapa tidak membawa tugas tajuk rencana, Nak?"

Siswa 1 : "Tidak ada saya dapat, Bu".

Siswa 2 : "Alasan iyero Bu, makuttu memeng iyero Bu”. (Alasan itu, Bu, memang dia sangat malas, $\mathrm{Bu}$ ). (Data 01.02).

Tuturan tersebut disampaikan oleh siswa kepada guru dan siswa kepada siswa pada saat guru menanyakan tugas siswa, terdapat seorang siswa tidak membawa tugas dan merespons pertanyaan guru, tiba-tiba seorang siswa menanggapi jawaban temannya. Penyimpangan maksim kearifan dan maksim kedermawanan pada data tersebut karena siswa tidak menunjukkan kearifan dan kedermawanan menyampaikan sebuah tuturan. Tuturan pada data tersebut menjadi tidak santun karena tuturan siswa tersebut yakni "alasan iyero Bu, makuttu memeng iyero $B u$ ”. (Alasan itu $\mathrm{Bu}$, memang dia sangat malas $\mathrm{Bu}$ ), terkesan siswa menegur dengan kata-kata yang kasar, tidak menghormati mitra tutur (memotong pembicaraan mitra tutur), dan mempermalukan mitra tutur. Tuturan menegur dengan kata-kata yang kasar, tidak menghormati mitra tutur (memotong pembicaraan mitra tutur), dan mempermalukan mitra tutur termasuk ke dalam tuturan yang tidak menunjukkan kearifan dan kedermawanan, sehingga tuturan siswa tersebut menyimpang dari prinsip kesantunan maksim kearifan dan kedermawanan.

1. Maksim kedermawanan dan maksim pujian Penyimpangan maksim kedermawanan dan maksim pujian yaitu peserta tutur melanggar maksim kedermawanan sekaligus maksim pujian. Penyimpangan maksim kedermawanan dan maksim pujian terjadi lima kali pada yang telah dianalisis. Penyimpangan maksim kedermawanan dan maksim pujian dapat dilihat pada data berikut.

Guru : "Sudah!, sekarang, yang sudah punya tajuk rencana, silakan dibaca dengan baik. Setelah itu, silakan ditulis rangkumannya di buku latihan Anda, tajuk rencana ditempel di buku tulisan dan rangkumannya ditulis di bawahnya. Sudah dimengerti?"

Siswa 1 : "Bagaimana lagi cara merangkum, $\mathrm{Bu}$ ?, wallupai sedding $\mathrm{Bu}$, ke siniki dulu Bu!'”(Saya lupa lagi $\mathrm{Bu}$, ke sini dulu, $\mathrm{Bu}$ ).

Siswa 2 : "Makkomemeng iyero $\mathrm{Bu}$, anre bawang ningngerrang". (Begitu memang dia $\mathrm{Bu}$, makan saja selalu dingat). (Data 01.04).

Tuturan tersebut disampaikan oleh siswa kepada guru dan siswa pada saat sedang menjelaskan cara mengerjakan tugas kepada siswa dan tiba-tiba seorang siswa bertanya kepada guru. Penyimpangan maksim kedermawanan dan maksim pujian pada data tersebut karena siswa tidak menunjukkan kedermawanan dan pujian menyampaikan sebuah tuturan. Tuturan pada data tersebut menjadi tidak santun karena tuturan siswa (2) tersebut yakni "makkomemeng iyero Bu, anre bawang ningngerrang”. (Begitu memang dia $\mathrm{Bu}$, makan saja selalu dingat), terkesan siswa memberi kritikan yang menjatuhkan kepada temannya dan berbicara yang menyakiti hati temannya dan siswa tersebut juga mempermalukan temannya. Tuturan memberi kritikan yang menjatuhkan kepada temannya dan berbicara yang menyakiti hati temannya dan siswa tersebut juga mempermalukan temannya, termasuk ke dalam tuturan yang tidak menunjukkan kedermawanan dan pujian, sehingga tuturan siswa tersebut menyimpang dari prinsip kesantunan maksim kedermawanan dan pujian.

2. Maksim kerendahan hati dan maksim kesepakatan

Penyimpangan maksim kerendahan hati dan maksim kesepakatan yaitu peserta tutur melanggar maksim kerendahan hati sekaligus maksim kesepakatan. Penyimpangan maksim kerendahan hati dan maksim kesepakatan dapat dilihat pada data berikut.

Guru : "Bagus sekali, masih ada yang lain, ingin memberikan penjelasan tentang fakta dan opini?

Siswa : "Tidak ada Bu, sama tadi yang disampaikan oleh teman, hehehe... hehehe...

Guru : "Sama ya, bisa diulangi?"

Siswa : "Wallupaini sedding Bu (sudah saya lupa $\mathrm{Bu}$ ), hehehe... pokokna pada nangnge iyero napauwe $\mathrm{Bu}$ (pokonya sama tadi yang disampaikan oleh teman Bu)". (Data 04.44).

Tuturan tersebut disampaikan oleh siswa kepada guru pada saat siswa ditanya oleh guru, namun dia tidak bisa mengulangi jawaban yang dianggap sama dengan jawaban temannya. Penyimpangan maksim kerendahan 
hati dan maksim kesepakatan pada data tersebut karena siswa tidak menunjukkan kerendahan hati dan kesepakatan menyampaikan sebuah tuturan. Tuturan pada data tersebut menjadi tidak santun karena tuturan siswa tersebut yakni "wallupaini sedding, $\mathrm{Bu}$ (sudah saya lupa $\mathrm{Bu}$ ), hehehe..., pokokna pada nangnge iyero napauwe $\mathrm{Bu}$ (pokonya sama tadi yang disampaikan oleh teman Bu)", terkesan siswa mencari-cari alasan dan tidak ada kesepakatan antara penutur dan mitra tutur. Tuturan yang mencari-cari alasan dan tidak ada kesepakatan antara penutur dan mitra tutur (guru), termasuk ke dalam tuturan yang tidak menunjukkan kerendahan hati dan kesepakatan, sehingga tuturan siswa tersebut menyimpang dari prinsip kesantunan maksim kerendahan hati dan kesepakatan.

\section{PEMBAHASAN}

Pembahasan penelitian yang telah dikemukakan pada bagian hasil penelitian. Selanjutnya, disajikan sesuai dengan urutan permasalahan yang diajukan, yaitu (a) Penyimpangan prinsip kesantunan berbahasa yang terjadi dalam interaksi belajar-mengajar bahasa Indonesia siswa kelas XI SMA Negeri 2 Panca Rijang Sidenreng Rappang, dan (b) penyebab penyimpangan prinsip kesantunan berbahasa yang terjadi dalam interaksi belajar-mengajar bahasa Indonesia siswa kelas XI SMA Negeri 2 Panca Rijang Sidenreng Rappang.

\section{1) Penyimpangan prinsip kesantunan berbahasa dalam interaksi belajar- mengajar bahasa Indonesia}

Pada tahap observasi awal di SMA Negeri 2 Panca Rijang Sidenreng Rappang, ditemukan bahwa guru bahasa Indonesia kelas XI sudah menerapkan prinsip kesantunan berbahasa. Namun, masih banyak siswa belum menerapkan prinsip kesantunan berbahasa. Oleh karena itu, peneliti telah melakukan tindak lanjut dalam hal ini, melakukan penelitian dengan merujuk pada dua rumusan masalah yang telah diuraikan. Berdasarkan hasil penelitian yang telah dilakukan diperoleh temuan bahwa jumlah seluruh penyimpangan prinsip kesantunan berbahasa dalam interaksi belajar-mengajar bahasa Indonesia di kelas XI SMA Negeri 2 Panca Rijang Sidenreng Rappang, sebanyak 131 tuturan, terdiri atas penyimpangan tunggal dan penyimpangan ganda. Secara umum, dapat pula diketahui bahwa hasil analisis data menunjukkan jumlah pertuturan yang menyimpang dari prinsip kesantunan berbahasa yang terjadi antara siswa dengan siswa dan guru sebanyak 124 tuturan dan antara guru dan siswa sebanyak tujuh tuturan.
Prinsip kesantunan yang paling banyak menyimpang dalam kategori penyimpangan tunggal adalah maksim kearifan, yaitu sebanyak 39 kali dengan persentase $30 \%$, penyimpangan maksim kedermawanan sebanyak 14 kali dengan persentase $11 \%$, penyimpangan maksim pujian sebanyak 4 kali dengan persentase 3\%, maksim kerendahan hati sebanyak 4 kali dengan persentase $3 \%$, penyimpangan maksim kesepakatan sebanyak 3 kali dengan persentase $2 \%$, dan penyimpangan maksim kesimpatian sebanyak 2 kali dengan persentase $1 \%$. Selanjutnya, dalam kategori penyimpangan ganda, prinsip kesantunan yang paling banyak menyimpang, yaitu maksim kearifan dan maksim kedermawanan sebanyak 34 kali dengan persentase $26 \%$, penyimpangan maksim kearifan dan maksim kesepakatan sebanyak 9 kali dengan persentase $7 \%$, penyimpangan maksim kearifan dan maksim pujian sebanyak 5 kali dengan persentase $4 \%$, penyimpangan maksim kearifan dan maksim kerendahhatian sebanyak 5 kali dengan persentase $4 \%$, penyimpangan maksim kedermawanan dan maksim pujian sebanyak 5 kali dengan persentase $4 \%$, penyimpangan maksim kearifan dan maksim kesimpatian sebanyak 4 kali dengan persentase 3\%, penyimpangan maksim kedermawanan dan maksim kesepakatan sebanyak 2 kali dengan persentase $1 \%$, dan maksim kerendahhatian dan maksim kesepakatan sebanyak 1 kali dengan persentase $1 \%$.

Berdasarkan uraian data hasil penelitian tersebut, diperoleh temuan bahwa dalam prinsip kesantunan berbahasa yang terdiri atas enam maksim, yaitu maksim kearifan, maksim kedermawanan, maksim pujian, maksim kerendahan hati, maksim kesepakatan, dan maksim kesimpatian (Leech, 1993: 206-207). Keenam maksim tersebut, ternyata ada satu jenis maksim yang kuntitas penyimpangan lebih tinggi atau tuturan peserta tutur lebih banyak menyimpang daripada kelima maksim yang lain pada penyimpangan tunggal. Maksim yang dimaksud adalah maksim kearifan. Hal tersebut terjadi karena penutur tidak berusaha memaksimalkan keuntungan mitra tutur dalam kegiatan bertutur, begitu pula sebaliknya.

Padahal, maksim kearifan menuntut setiap peserta tutur berpegang teguh dengan prinsip untuk mengurangi keuntungan diri sendiri dan memaksimalkan mitra tutur dalam kegiatan bertutur. Selain itu, orang yang bertutur senantiasa berpegang teguh dalam melaksanakan maksim kearifan sehingga ia dapat menghindarkan sikap dengki, iri hati, dan sikap-sikap lain yang kurang santun terhadap mitra tutur (Rahardi, 2005:60). Selanjutnya, pada penyimpangan ganda, 
maksim kearifan dan maksim kedermawanan memiliki kuantitas penyimpangan yang tinggi. Hal tersebut terjadi karena penutur tidak memaksimalkan keuntungan mitra tutur dalam kegiatan bertutur dan penutur tidak memaksimalkan rasa hormat kepada mitra tutur, begitu pula sebaliknya.

Secara umum, penyimpangan prinsip kesantunan yang terjadi tentu saja menjadi perhatian utama semua pihak, mengingat kesantunan berbahasa merupakan perilaku yang diekspresikan dengan cara yang baik atau beretika dengan tujuan membuat suasana berinteraksi menyenangkan, beretika, dan efektif. Oleh karena itu, peserta tutur harus senantiasa memperhatikan prinsip-prinsip kesantunan berbahasa supaya tuturan yang disampaikan dapat berterima oleh mitra tutur dan tidak menimbulkan kesan yang tidak santun. Hal tersebut berkaitan dengan teori utama yang mengatakan bahwa peserta tutur hendaknya dapat menggunakan strategi dalam berinteraksi, yaitu bertutur secara jelas, bersopan santun, dan senantiasa memperhatikan nilai-nilai pendukung kesantunan berbahasa. (Pranowo, 2009).

Berdasarkan uraian tersebut dapat disimpulkan bahwa peserta tutur (siswa dan guru) hendaknya memperhatikan dan menerapkan prinsip dan skala-skala pengukur kesantunan berbahasa agar tuturan yang disampaikan tidak menyimpang dari prinsip kesantunan berbahasa yang terdiri atas enam maksim. Adapun skala-skala pengukur kesantunan berbahasa, dapat dirinci sebagai berikut. (1) Cost benefit scale atau skala kerugian dan keuntungan, menunjuk kepada besar kecilnya kerugian dan keuntungan yang diakibatkan oleh sebuah tindak tutur pada sebuah pertuturan. Semakin tuturan tersebut merugikan diri penutur, akan semakin dianggap santunlah tuturan itu. Demikian sebaliknya, semakin tuturan itu menguntungkan diri penutur akan semakin dianggap tidak santunlah tuturan itu (Rahardi, 2005:67). (2) Optionality scale atau skala pilihan, menunjuk kepada banyak atau sedikitnya pilihan (options) yang disampaikan si penutur kepada si mitra tutur di dalam kegiatan bertutur. Semakin pertuturan itu memungkinkan penutur atau mitra tutur menentukan pilihan yang banyak dan leluasa, akan dianggap semakin santunlah tuturan itu. Sebaliknya, apabila pertuturan itu sama sekali tidak memberikan kemungkinan memilih bagi si penutur dan si mitra tutur, maka tuturan sbut dianggap tidak santun (Rahardi, 26 5:67). (3) Indirectness scale atau skala ketidaklangsungan menunjuk kepada peringkat langsung atau tidak langsungnya maksud sebuah tuturan. Semakin tuturan itu bersifat langsung akan dianggap semakin tidak santunlah tuturan itu. Demikian sebaliknya, semakin tidak langsung, maksud sebuah tuturan, akan dianggap semakin santunlah tuturan itu (Rahardi, 2005:67). (4) Authority scale atau skala keotoritasan menunjuk kepada hubungan status sosial antara penutur dan mitra tutur yang terlibat dalam pertuturan. Semakin jauh jarak peringkat sosial (rank rating) antara penutur dengan mitra tutur, maka tuturan yang digunakan akan cenderung menjadi semakin santun. Sebaliknya, semakin dekat jarak peringkat status sosial di antara keduanya, maka akan cenderung berkuranglah peringkat kesantunan tuturan yang digunakan dalam bertutur itu (Rahardi, 2005:67). (5) Social distance scale atau skala jarak sosial menunjuk kepada peringkat hubungan sosial antara penutur dan mitra tutur yang terlibat dalam sebuah pertuturan. Ada kecenderungan bahwa semakin dekat jarak peringkat sosial di antara keduanya, akan menjadi semakin kurang santunlah tuturan itu. Sebaliknya, semakin jauh jarak peringkat sosial antara penutur dengan mitra tutur, akan semakin santunlah tuturan yang digunakan itu (Rahardi, 2005:67).

\section{2) Penyebab penyimpangan prinsip kesantunan berbahasa dalam interaksi belajar-mengajar bahasa Indonesia}

Penyebab penutur dan mitra tutur melakukan penyimpangan prinsip kesantunan bermacam-macam. Berdasarkan hasil analisis data yang dideskripsikan dalam tabel (halaman 147), menunjukkan bahwa penyebab penyimpangan yang sering muncul yaitu kritikan secara langsung dengan kata-kata yang kasar, dorongan rasa emosi penutur, protektif terhadap pendapat, dan mengejek. Siswa dan guru dalam bertutur /berkomunikasi tampaknya masih sering memberi kritikan secara langsung dengan kata-kata yang kasar karena dipengaruhi oleh dorongan rasa emosi yang berlebihan sehingga tuturan yang dihasilkan menyimpang dari prinsip kesantunan berbahasa.

Berdasarkan uraian tersebut dapat disimpulkan bahwa temuan yang diperoleh dalam penelitian ini, yaitu penyimpangan prinsip kesantunan berbahasa dalam interaksi belajar mengajar bahasa Indonesia di kelas XI SMA Negeri 2 Panca Rijang Sidenreng Rappang, sebanyak 131 tuturan, terdiri atas penyimpangan tunggal dan penyimpangan ganda. Penyebab penyimpangan yang sering muncul yaitu kritikan secara langsung dengan kata-kata yang kasar, dorongan rasa emosi penutur, protektif terhadap pendapat, dan mengejek. Siswa dan guru dalam bertutur/berkomunikasi tampaknya masih sering memberi kritikan secara langsung dengan kata-kata yang kasar karena 
dipengaruhi oleh dorongan rasa emosi yang berlebihan sehingga tuturan yang dihasilkan menyimpang dari prinsip kesantunan berbahasa.

Temuan penelitian tersebut didukung oleh teori utama, yakni teori Geoffrey Leech (1993:206-207) mengenai prinsip kesantunan berbahasa. Selain itu, secara pragmatik, teori yang mengatakan bahwa berbicara tidak selamanya berkaitan dengan masalah yang bersifat tekstual. Akan tetapi, sering pula berkaitan dengan persoalan yang bersifat interpersonal. Oleh karena itu, dalam berbicara dibutuhkan kesantunan berbahasa (Wijana, 1996:55), sehingga peserta tutur hendaknya dapat mamahami dan menerapkan prinsip kesantunan berbahasa sebagai wujud ekspresi dengan cara yang baik atau beretika.

Selain itu, temuan penelitian ini didukung oleh hasil wawancara guru dan siswa. Hasil wawancara yang dilakukan menunjukkan bahwa penyimpangan prinsip kesantunan berbahasa dalam interaksi belajarmengajar bahasa Indonesia siswa kelas XI SMA Negeri 2 Panca Rijang Sidenreng Rappang sangat tinggi. Oleh karena itu, kombinasi antara hasil temuan penelitian yang didasarkan pada hasil rekaman dan teknik catat (data yang telah dianalisis) dengan hasil wawancara kepada guru kepada siswa mendukung hasil penelitian.

\section{PENUTUP}

Berdasarkan hasil penelitian dan pembahasan mengenai penyimpangan prinsip kesantunan berbahasa dalam interaksi belajar mengajar bahasa Indonesia siswa kelas XI SMA Negeri 2 Panca Rijang Sidenreng Rappang, maka dapat disimpulkan bahwa penyimpangan prinsip kesantunan berbahasa dalam interaksi belajar mengajar bahasa Indonesia siswa kelas XI SMA Negeri 2 Panca Rijang Sidenreng Rappang meliputi penyimpangan tunggal dan penyimpangan ganda. Penyimpangan tunggal meliputi penyimpangan maksim kearifan, penyimpangan maksim kedermawanan, penyimpangan maksim pujian, penyimpangan maksim kerendahan hati, penyimpangan maksim kesepakatan, dan penyimpangan maksim kesimpatian, sedangkan penyimpangan ganda meliputi penyimpangan maksim maksim kearifan dan maksim kedermawanan, penyimpangan maksim kearifan dan maksim kesepakatan, penyimpangan maksim kearifan dan maksim pujian, penyimpangan maksim kearifan dan maksim kerendahan hati, penyimpangan maksim kedermawanan dan maksim pujian, penyimpangan maksim kearifan dan maksim kesimpatian, penyimpangan maksim kedermawanan dan maksim kesepakatan, dan maksim kerendahan hati dan maksim kesepakatan. Jenis penyimpangan yang paling sering muncul yaitu maksim kearifan/kebijaksaan, yaitu sebanyak 39 kali dengan persentase $30 \%$. Penyebab penyimpangan prinsip kesantunan berbahasa dalam interaksi belajar mengajar bahasa Indonesia siswa kelas XI SMA Negeri 2 Panca Rijang Sidenreng Rappang meliputi penyimpangan disebabkan oleh penutur sengaja menuduh mitra tutur, sengaja berbicara tidak sesuai konteks, protektif terhadap pendapat, dorongan rasa emosi penutur, penutur sengaja memojokkan mitra tutur, kritik secara langsung dengan kata-kata kasar, dan mengejek serta tidak memberikan rasa simpati kepada mitra tutur. Penyebab penyimpangan yang paling sering muncul yaitu kritik secara langsung dengan kata-kata yang kasar, dorongan rasa emosi penutur, dan mengejek.

\section{DAFTAR PUSTAKA}

Amiruddin. 2011. Penggunaan Tindak Tutur Direktif Guru dalam Interaksi Pembelajaran (Studi Etnografi Komunikasi di SMP Negeri 3 Pitu Riase Sidrap). Tesis. Tidak diterbitkan. Malang: Program Pascasarjana Universitas Negeri Malang.

Arikunto, Suharsimi. 1993. Manajemen Penelitian. Jakarta: Rineka Cipta.

Chaer, Abdul. 2010. Kesantunan Berbahasa. Jakarta: Rineka Cipta.

Chaer, Abdul dan Leonie Agustina. 1995. Sosiolinguistik Perkenalan Awal. Jakarta: Rineka Cipta.

Dimyanti. 1992. Strategi Belajar-Mengajar. Jakarta: Departemen Pendidikan dan Kebudayaan.

Eelen, Gino. 2006. Kritik Teori Kesantunan. Surabaya: Airlangga University Press.

Gunarwan, Asim. 2007. Implikatur dan Kesantunan Berbahasa: Beberapa Tilikan dalam Sandiwara Ludruk, dalam Yassir Nasanius (Ed.), PELLBA 18 (hlm. 85-120). Jakarta: Universitas Katolik Indonesia, Atmajaya Jakarta, dan Yayasan Obor Indonesia.

Hanafi, Muhammad. 2014. Representasi Kesantunan Imperatif dalam Wacana Akademik di STKIP Muhammadiyah Sidrap (Kajian Sosiopragmatik). Disertasi tidak diterbitkan. Makassar: Program Pascasarjana Universitas Hasanuddin Makassar.

Ide, Sachiko. 1986. Formal From and Discernment: Two Neglected Aspects of University of Linguisties 
Politeness. Multilingual, 8/2-3:223248.

Iskandar. 2008. Metode Penelitian Pendidikan dan Sosial: Jakarta. GP Press.

Kridalaksana. 1982. Fungsi Bahasa dan Sikap Bahasa. Ende Flores: Nusa Indah.

Kushartanti B. 2009. Strategi Kesantunan Bahasa pada Anak-anak Usia Prasekolah: Mengungkapkan Keinginan. Jurnal Linguistik Indonesia, 27 (2): 247-256.

Leech, Geoffrey. 1993. Prinsip-Prinsip Pragmatik (terjemahan M.D.D. Oka). Jakarta: UI Press.

Levinson, Stephen. 1983. Pragmatics. Cambridge: Unversity Press.

Mahsun. 2005. Metode Penelitian Bahasa. Yogyakarta: Duta Wacana University Press.

Markhamah. 2011. Analisis Kesalahan dan Kesantunan Berbahasa. Surakarta: Muhammadiyah University Press.

Moleong, Lexy J. 1990. Metode Penelitian Kualitatif. Bandung: Reuga Posdakarya.

Mulyana.2005. Kajian Wacana. Yogyakarta: Tiara Wacana.

Musaba, Zulkifli. 2012. Terampil Berbicara: Teori dan Pedoman Penerapannya. Yogyakarta: $\quad$ CV Aswaja Pressindo.

Parera, Jos Daniel. 1999. Pedoman Kegiatan Belajar Mengajar Bahasa Indonesia. Jakarta: Grasindo.

Pranowo. 2009. Berbahasa Secara Santun. Yogyakarta: Pustaka Pelajar.

Pusat Bahasa Departemen Pendidikan Nasional. 2005. Kamus Besar Bahasa Indonesia (Edisi revisi ketiga). Jakarta: Balai Pustaka.

Rahardi, Kunjana. 2005. Pragmatik; Kesantunan Imperatif Bahasa Indonesia. Jakarta: Erlangga.

Sardiman. 2010. Interaksi dan Motivasi Belajar-Mengajar. Jakarta: Rajawali Press.

Sudaryanto. 2003. Metodologi Penelitian Pengajaran Bahasa. Handout. Yogyakarta: Program Studi Pendidikan Bahasa dan Sastra Indonesia, FBS, UNY.

Semi, Atar. 1990. Rancangan Pengajaran Bahasa dan Sastra Indonesia. Bandung: Angkasa.
Soeparno. 2002. Dasar-Dasar Linguistik Umum. Yogyakarta: Tiara Wacana.

Suharto, Rus. 2004. Kesantunan Berbahasa Indonesia dalam Interaksi BelajarMengajar di Kelas VIII SMP. Tesis. Tidak diterbitkan. Malang: Program Pascasarjana Universitas Muhammadiyah Malang.

Suryosubroto. 1997. Belajar dan Pembelajaran. Jakarta: PT Rineka Cipta.

Syafruddin. 2010. Kesantunan Honorifik dalam Tindak Direktif Berbahasa Indonesia Keluarga Terpelajar Masyarakat Tutur Makassar. Disertasi. Tidak diterbitkan. Malang: Program Pascasarjana Universitas Muhammadiyah Malang.

Wahab, Abdul. 2004. Kesantunan Penolakan Berbahasa Indonesia di Kalangan Masyarakat Aceh Utara yang Ada di Malang. Tesis. Tidak diterbitkan. Malang: Program Pascasarjana Univers itas Muhammadiyah Malang.

Wijana, I Dewa Putu dan Rohmadi M. 1996. Dasar-Dasar Pragmatik. Yogyakarta: Andi.

. 2009. Analisis Wacana Pragmatik. Surakarta: Yuma Pustaka.

Yule, George. 1996. Pragmatik. Terjemahan oleh Indah Fajar Wahyuni. Yogyakarta. Pustaka Pelajar.

Zamzani, dkk. 2010. Pengembangan Alat Ukur Kesantunan Bahasa Indonesia dalam Interaksi Sosial Bersemuka dan Non Bersemuka. Laporan Penelitian Hibah Bersaing (Tahun Kedua). Yogyakarta: Universitas Negeri Yogyakarta.

2011. Pengembangan Alat Ukur Kesantunan Bahasa Indonesia dalam Interaksi Sosial Bersemuka. LITERA, (online) Vol. 10, No. 1 (https://www.google.co.id/webhp?ie= utf-8\&oe $=$ utf

8\&gws_rd=cr\&ei=SycxV46TM4OYu QTwrbS4Bw\#q=jurnal+pengembang an+alat+ukur+kesantunan+berbahasa, Diakses 10 April 2016). 